МІНІСТЕРСТВО ОСВІТИ І НАУКИ УКРАЇНИ

СУМСЬКИЙ ДЕРЖАВНИЙ УНІВЕРСИТЕТ

КАФЕДРА ІНОЗЕМНИХ МОВ

ЛІНГВІСТИЧНИЙ НАВЧАЛЬНО-МЕТОДИЧНИЙ ЦЕНТР

\author{
МАТЕРІАЛИ ХІ ВСЕУКРАЇНСЬКОЇ \\ НАУКОВО-ПРАКТИЧНОЇ КОНФЕРЕНЦЇ̈ \\ СТУДЕНТІВ АСПІРАНТІВ ТА ВИКЛАДАЧІВ \\ ЛІНГВІСТИЧНОГО НАВЧАЛЬНО-МЕТОДИЧНОГО \\ ЦЕНТРУ КАФЕДРИ ІНОЗЕМНИХ МОВ
}

“TO MAKE THE WORLD SMARTER AND SAFER"

(Суми, 23 березня 2017 року) 
MINISTRY OF EDUCATION AND SCIENCE OF UKRAINE SUMY STATE UNIVERSITY FOREIGN LANGUAGES DEPARTMENT

LANGUAGE CENTRE

\author{
MATERIALS OF THE ELEVENTH \\ ALL UKRAINIAN SCIENTIFIC PRACTICAL \\ STUDENTS', POSTGRADUATES' AND INSTRUCTORS' \\ CONFERENCE OF LANGUAGE CENTRE OF THE \\ FOREIGN LANGUAGES DEPARTMENT
}

"TO MAKE THE WORLD SMARTER AND SAFER"

(Sumy, March 23, 2017) 
before they were either completely incurable, now it is possible to treat them "truly", that is to eliminate the very cause of the disease.

\section{NANOTECHNOLOGY IN MEDICINE}

A. Svikolnik - Sumy State University, group LS - 501

L. A. Denisova - E L Adviser

In today's world often facing humanity faces global problems. Significant help in solving various problems can provide nanotechnology. In some biology and other sciences often use them is crucial.

I have said that over the past few decades was found about thirty infectious pathologies. Among them we should mention AIDS, "bird flu" virus, Ebola and others. Every year millions worldwide are diagnosed new cases of cancer. Mortality from these pathologies is around five hundred thousand people a year.

Nanotechnology in medicine is of great importance for all humanity. The advantages of using advanced methods over traditional therapy are obvious. Nanotechnology in medicine mainly involves chemical effect on a particular disease by administering drugs. Examples of the use of nanotechnology in medicine are a lot. Thus, scientists have created a new class of particles. Nanoparticles endowed with unique properties of optical character. These elements, having a microscopic diameter can move freely through the blood system. To the surface liners attached antibodies. The purpose of the application of nanotechnology in medicine is the destruction of cancer cells. A few hours after the liner into the body, made an infrared light irradiation. Inside is the formation of a special power by which cancer cells and destroyed.

Scientists suggest that this and other nanotechnology in medicine will contribute to the development of operational and inexpensive diagnostic methods and eliminate abnormalities early. In addition, new developments in the field of drugs may permit repair damaged DNA structure.

Using nanotechnologies, science can provide personal immortality to people due to implementation in an organism of molecular robots. They will be able to prevent cell aging, reorganize 
tissues of human body, resuscitate treatment for hopelessly sick people who have been contemporarily frozen using cryonic methods.

\section{INNOVATIONS IN MEDICINE \\ D. Taranyuk - SSU, group PM - 61 \\ S.G. Zolotova - E L Adviser}

Whether it's the technology that allows us to peer deep into the body or medicines that extend the lives of those with chronic diseases, it's easy to see how advances in health and medicine have touched the lives of nearly every person on the planet. The list below encompasses 10 Medical Breakthroughs in health and medical practices that have changed - and in many ways continue to change the world today.

The bionic eye takes a video signal from a camera built into sunglasses and wirelessly transmits that image to implants in the retinas of people who have lost their vision. The system isn't perfect. It lets a blind person regain basic functions like walking on a sidewalk without stepping off a curb, and distinguishing black from white socks. Plus, as the retina itself heals over the implant, the quality of vision decreases. The bionic eye is currently only approved for people who have lost their sight from retinal pigmentosis.

The seizure stopper is a new innovation for epileptics suffering people. It is like a defibrillator for brain, the system includes sensors implanted in the brain that can spot the first tremors of an oncoming seizure. Then it sends electrical pulses that counteract the brain's own haywire signals, stopping the seizure in its tracks.

Until recently, treatment for hepatitis $\mathrm{C}$ fell into the good-butnot-great category, with only around 70 percent of patients being cured. The new drug Sofosbuvir is a much more potent killer of hep $\mathrm{C}$, with success in as many as 95 percent of patients. 